\title{
Purification of the Major Outer Membrane Protein of Azospirillum brasilense, Its Affinity to Plant Roots, and Its Involvement in Cell Aggregation
}

\author{
Saul Burdman, ${ }^{1}$ Gabriella Dulguerova, ${ }^{2}$ Yaacov Okon, ${ }^{1}$ and Edouard Jurkevitch ${ }^{1}$ \\ ${ }^{1}$ Department of Plant Pathology and Microbiology and the Otto Warburg Center for Agricultural \\ Biotechnology, Faculty of Agricultural, Food and Environmental Quality Sciences, Hebrew University of \\ Jerusalem, P. O. Box 12, Rehovot 76100, Israel; ${ }^{2}$ Department of Pharmacology and Toxicology, Faculty \\ of Medicine, Medical University, 1431 Sofia, Bulgaria \\ Accepted 12 December 2000.
}

\begin{abstract}
The major outer membrane protein (MOMP) of the nitrogen-fixing rhizobacterium Azospirillum brasilense strain Cd was purified and isolated by gel filtration, and antiserum against this protein was obtained. A screening of the binding of outer membrane proteins (OMPs) of $A$. brasilense to membrane-immobilized root extracts of various plant species revealed different affinities for the MOMP, with a stronger adhesion to extracts of cereals in comparison with legumes and tomatoes. Moreover, this protein was shown to bind to roots of different cereal seedlings in an in vitro adhesion assay. Incubation of $A$. brasilense cells with MOMP-antiserum led to fast agglutination, indicating that the MOMP is a surface-exposed protein. Cells incubated with Fab fragments obtained from purified MOMP-antiserum immunoglobulin G exhibited significant inhibition of bacterial aggregation as compared with controls. Bacteria preincubated with Fab fragments showed weaker adhesion to corn roots in comparison to controls without Fab fragments. These findings suggest that the $A$. brasilense MOMP acts as an adhesin involved in root adsorption and cell aggregation of this bacterium.
\end{abstract}

Additional keywords: flocculation, root attachment.

Azospirillum brasilense is a gram-negative $\mathrm{N}_{2}$-fixing rhizobacterium that lives in close association with plant roots and exerts positive effects on plant growth and yield of many crops of agronomic importance (Okon and LabanderaGonzales 1994). These effects are derived mainly from morphological and physiological changes of the inoculated plant roots, which lead to improved water uptake and mineral utilization (Okon and Vanderleyden 1997).

Attachment of $A$. brasilense to roots is an essential step for the establishment of an efficient association with the host plant (De Troch and Vanderleyden 1996). A. brasilense cells are able to aggregate under certain environmental conditions, leading to the formation of bacterial flocs with this property probably positively affecting their dispersal and survival in

Corresponding author: E. Jurkevitch; Telephone: +972 8 9489167; Fax: +972 8 9466794; E-mail: jurkevi@agri.huji.ac.il soil (Sadasivan and Neyra 1985). Data suggesting the involvement of extracellular proteins and polysaccharides in aggregation and root adsorption of $A$. brasilense have been reported. Moreover, both processes seem to share at least part of these components (Burdman et al. 2000c).

Evidence supporting the involvement of outer membrane proteins (OMPs) in cell aggregation of $A$. brasilense was provided with an aggregation bioassay (Burdman et al. 1999). In the last decade, OMPs (more specifically, porins) have been proposed to play a role as adhesins in various gram-negative bacteria (Burdman et al. 2000c). Moreover, the major OMPs (MOMPs) of two rhizosphere bacteria, Pseudomonas fluorescens and Rahnella aquatilis, act as adhesins because they adhere strongly to plant roots (Achouak et al. 1995; De Mot and Vanderleyden 1991).

The MOMP of A. brasilense constitutes about $60 \%$ of the total OMPs (Bachhawat and Ghosh 1987). The gene encoding this protein recently was isolated, sequenced, and analyzed, and the deduced amino acid sequence suggested that the mature MOMP contains 367 amino acids with a molecular mass of 38,753 Da (Burdman et al. 2000a). The deduced amino acid sequence showed low, yet significant, homology to certain bacterial porins. Outer membrane protein analysis and multiple alignment with the closest homologous sequences predict that this protein possesses cell surface-exposed domains that could be involved in the above adhesion processes (Burdman et al. 2000a).

In this work, we report on the purification of the MOMP from $A$. brasilense strain $\mathrm{Cd}$ and present data linking this protein to bacterial adhesion processes.

\section{RESULTS}

Isolation of the MOMP

of $A$. brasilense and antiserum production.

An outer membrane (OM) preparation of A. brasilense strain Cd was loaded onto a Superdex-200 column (gel filtration) in a fast protein liquid chromatography (FPLC). Solubilization was achieved by adding sodium dodecyl sulfate (SDS) to a final concentration of $0.1 \%$ to the sample and to the separating buffer. The profile of the protein separation is shown in 
Figure 1. Because of the expected molecular mass (approximately $40 \mathrm{kDa}$, as estimated by SDS-polyacrylamide gel electrophoresis [PAGE]) and its abundance (approximately $60 \%$ of total OMPs), the second peak (7.0 to $11.0 \mathrm{ml})$ was

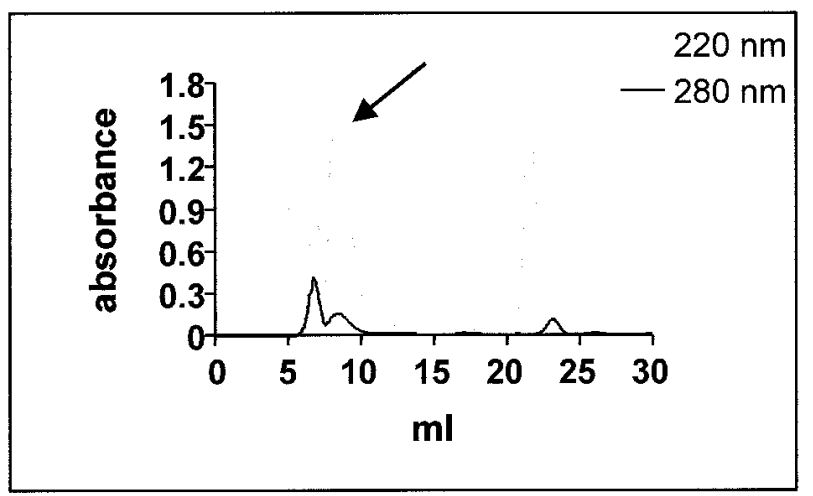

Fig. 1. Separation of the outer membrane proteins (OMPs) from Azospirillum brasilense strain $\mathrm{Cd}$ by fast protein liquid chromatography with a Superdex-200 column. Separation was carried out at a flow rate of $0.2 \mathrm{ml}$ per min with $20 \mathrm{mM}$ Tris- $\mathrm{HCl}$ buffer $(\mathrm{pH}$ 7.2) containing $100 \mathrm{mM} \mathrm{NaCl}$ and $0.1 \%$ sodium dodecyl sulfate. Absorbance values at 220 and $280 \mathrm{~nm}$ were recorded every $5.12 \mathrm{~s}$. Arrow indicates the peak that corresponds to the major OMP. suspected of containing the MOMP. Samples from tubes containing this second peak (tubes 12 to 15 , corresponding to elution volumes 8.0 to $10.0 \mathrm{ml}$ ) were subjected to SDS-PAGE. Only one band of approximately $40 \mathrm{kDa}$ was observed in these samples, indicating that this peak corresponded to the $A$. brasilense MOMP (Fig. 2A). Subsequently, the tubes were pooled, concentrated by speed vacuum, and used for antiserum production.

The antiserum against the MOMP was shown to react specifically with this protein (Fig. 2B). A. brasilense wild-type strains Sp7 and Sp245 showed an identical OMP pattern to that of strain $\mathrm{Cd}$ and an identical reactivity of their MOMP to the antiserum (Fig. 2B).

\section{Affinity of the $A$. brasilense MOMP to roots.}

Various amounts of root extracts from a variety of plant species were blotted directly onto nitrocellulose membranes, incubated with $\mathrm{OM}$ preparation from A. brasilense strain $\mathrm{Cd}$, and subjected to immunodetection with the antiserum. The MOMP exhibited different affinities to the various root extracts. Stronger adhesion to root extracts from cereals (wheat, corn, and sorghum) in comparison to root extracts of the other tested plants was clearly observed (Fig. 3). An identical pattern of affinity was observed when the purified MOMP was used instead of the OM preparation as well as when OM

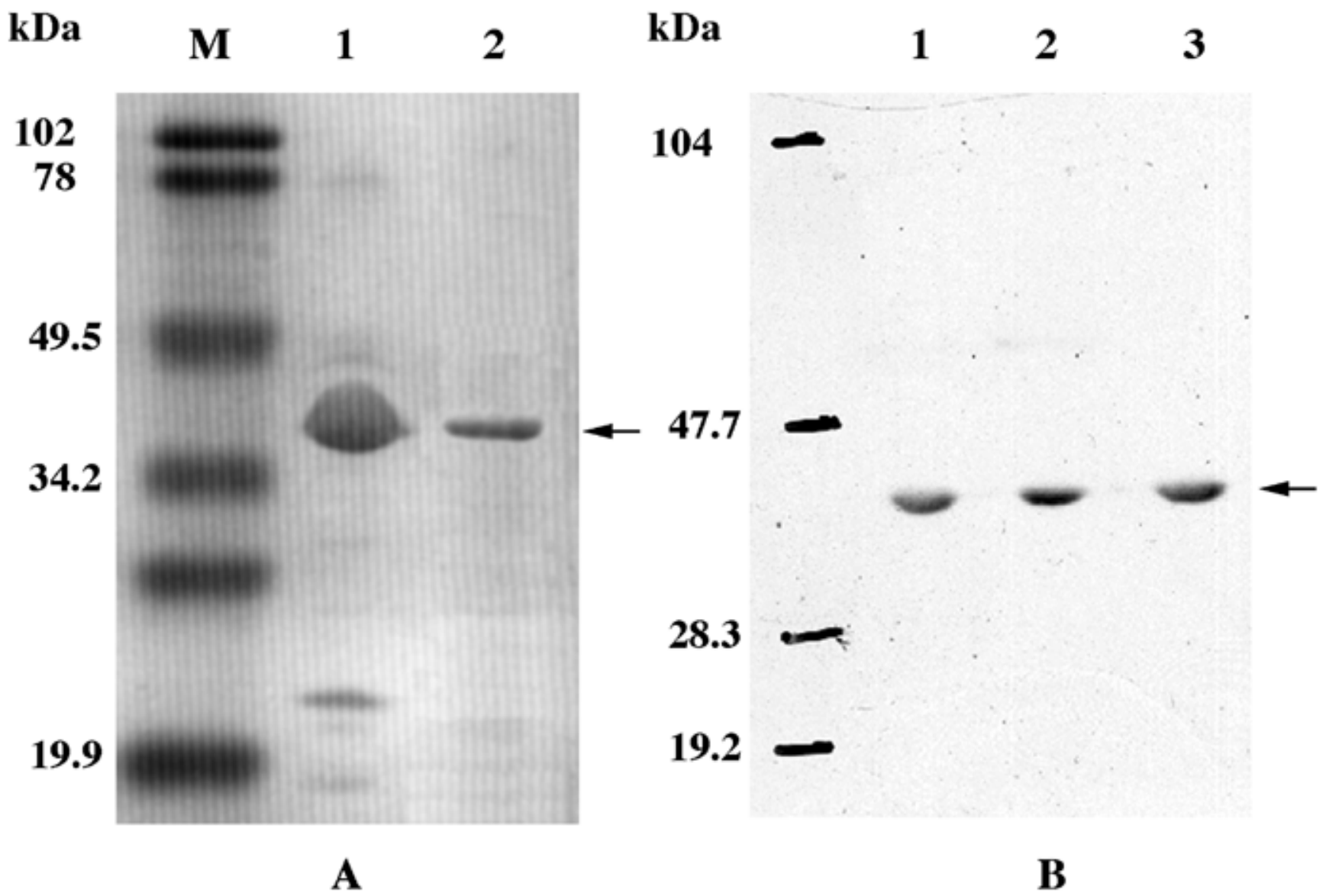

Fig. 2. A, Sodium dodecyl sulfate-polyacrylamide gel electrophoresis of outer membrane proteins (OMPs) (lane 1) and of the pool of tubes $12-15$ from the fast protein liquid chromatography separation (lane 2). B, Immunodetection of the Azospirillum brasilense major OMP (MOMP) with antiserum obtained against the purified MOMP from strain Cd. OMPs of strains Cd (lane 1), Sp7 (lane 2), and Sp245 (lane 3). Arrows indicate the position of the MOMP band. 
preparations from strains $\mathrm{Sp} 7$ and $\mathrm{Sp} 245$ (not shown) were used.

Roots of 1-week-old sweet corn seedlings were used in an adhesion assay. Figure 4 shows that, unlike the control, roots incubated with $\mathrm{OM}$ preparation of strain Cd reacted positively to MOMP antiserum, thus indicating that this protein adhered to the roots and remained bound to them after thorough washing. Roots incubated with bovine serum albumin (BSA) at the same concentration as the OMPs and treated in the same manner did not react with anti-BSA antibodies (not shown), indicating that, unlike the MOMP, BSA did not attach to the roots and the washing procedure was able to remove unbound protein from the roots to levels beyond detection. When the adhesion assay was performed with the purified MOMP, a similar signal was obtained, although not as strong as the one obtained with the OM preparation (not shown). This may be a result of structural modifications caused to the MOMP during the purification process.

Similar results to those obtained in the adhesion assay with corn roots were observed for sorghum and wheat. In contrast, roots of tomato and common bean showed a lower affinity to the MOMP, which is in accordance with the results obtained in the adhesion screening with root extracts.

\section{Effects of anti-MOMP Fab fragments} on cell aggregation and bacterial adhesion of $A$. brasilense.

The influence of anti-MOMP Fab fragments on aggregation and adhesion of $\mathrm{Cd}$ cells to sweet corn roots was tested. Fab fragments were used instead of antiserum or purified immunoglobulin G (IgG) against the MOMP because these were seen to cause agglutination of the cells after a short incubation period (Fig. 5).

A reduction in flocculation was observed after incubation of aggregating cells in the presence of anti-MOMP Fab fragments, as compared to the last eluted fraction from the Fab purification process (EF), BSA, and untreated controls. These results were confirmed statistically by dilution plating of the cells remaining in the liquid phase (in opposition to precipitated flocs), with a significantly higher bacterial concentration measured in the suspension of Fab-treated cells than in the control suspensions (Fig. 6).

It also was observed that EF-treated cell suspensions showed an intermediate bacterial concentration between the Fab fragment-treated suspensions and the controls (Fig. 6).

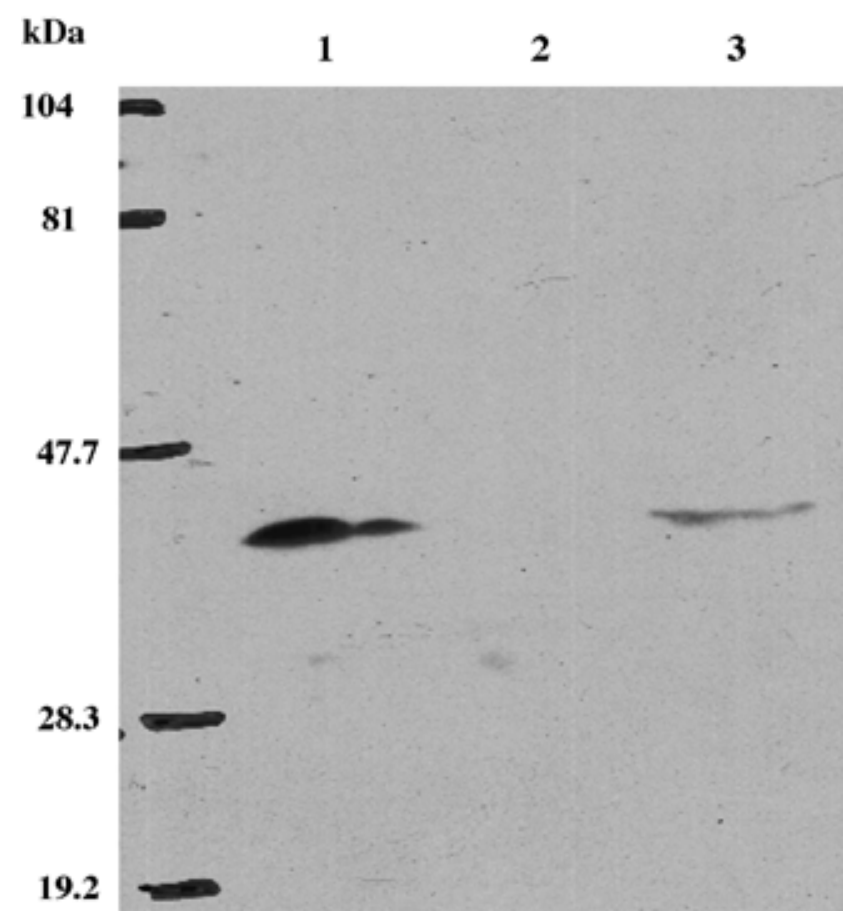

Fig. 4. Immunodetection of the Azospirillum brasilense major outer membrane proteins (MOMP) with MOMP antiserum. Outer member proteins of strain Cd (lane 1) and extract from corn roots that were incubated (lane 3) or not (lane 2) with the outer membrane preparation from strain $\mathrm{Cd}$.

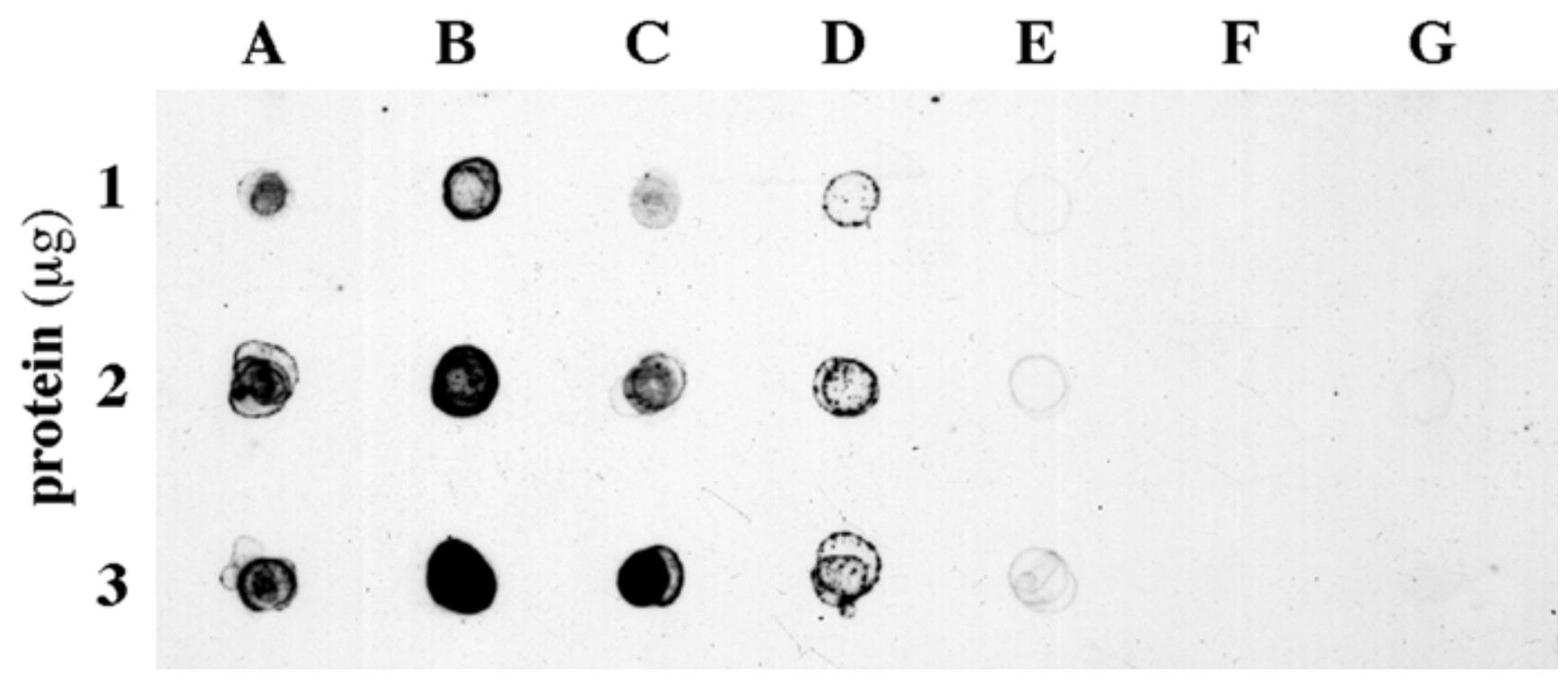

Fig. 3. Screening of adhesion of the Azospirillum brasilense major outer membrane proteins (MOMP) to different membrane-immobilized root extracts at various protein amounts (1-3 $\mu \mathrm{g}$ ) with MOMP antiserum. A, Sorghum, B, wheat, $\mathbf{C}$, forage corn, D, common bean, E, chickpeas, $\mathbf{F}$, tomato, G, bovine serum albumin (control). 
This is probably a result of the presence of a residual amount of Fab fragments in the EF fraction.

Preincubation of the bacteria with $\mathrm{Fab}$ fragments was shown to affect their adsorption to roots of 1-week-old sweet corn seedlings. In all treatments, most of the bacteria were released after vigorous vortexing of the samples. A significantly higher percentage of cells was released from roots incubated with Fab-treated bacteria than from control treatments, as observed by dilution plating (Table 1). These results indicate that the anti-MOMP Fab fragments significantly weakened the adhesiveness of the cells to the roots. This reduction in cell adsorption to corn roots by Fab-treated cells was confirmed in one experiment with ${ }^{14} \mathrm{C}$-labeled bacteria. Radiation counts discriminated between cells released and those remaining attached to the roots following vortex (Table 1), clearly showing the influence of Fab fragments on cell adsorption to the roots.

Data obtained from the experiments on the incorporation of radiolabeled sugars are more precise than those obtained by dilution plating because, in the latter, not all of the bacterial cells were released from the homogenized roots.

\section{DISCUSSION}

Previous characterization of the omaA gene encoding the $A$. brasilense MOMP revealed that its deduced amino acid sequence significantly resembles those of certain gram-negative bacteria porins or, more specifically, those of Rhodobacter capsulatus, Rhodopseudomonas blastica, and to a lesser extent Paracoccus denitrificans porin (Burdman et al. 2000a). Attempts to knock out the $o m a A$ gene by insertion of an antibiotic resistance cassette and homologous recombination were unsuccessful, suggesting that this mutation may be lethal in $A$. brasilense (Burdman et al. 2000a). In addition to its putative role as a porin, it is probable that, as a result of its abundance in the outer membrane, the MOMP is instrumental in stabilizing the OM structure.

The MOMP of A. brasilense strain Cd was purified and isolated by FPLC and antiserum against this protein was obtained. The antiserum was used for detection of the MOMP, and it was shown that this protein adheres to root extracts and to intact roots of different plant species. De Mot and Vanderleyden (1991) used the two-dimensional PAGE technique to show that the MOMP of $P$. fluorescens (OprF) adsorbs strongly to plant roots. Similar results were obtained by Achouak et al. (1995) with a 38-kDa MOMP of $R$. aquatilis that attached strongly to wheat roots. In both cases, the MOMPs were proposed to play a role in the attachment and colonization of plant roots by those bacteria.

The MOMP antiserum was shown to cause rapid bacterial agglutination, thus strengthening previous analytical data and suggesting that this protein contains cell surface-exposed domains that could be involved in adhesion processes of $A$. brasilense (Burdman et al. 2000a). Achouak et al. (1995) showed that antibodies directed against the 38-kD MOMP of $R$. aquatilis are able to bind to whole cells and strongly reduce their attachment to wheat roots. In the present study, anti-MOMP Fab fragments were used to assess the involvement of the MOMP in cell aggregation and root adsorption because antiserum and anti-MOMP IgG caused cell agglutination. In fact, the anti-MOMP Fab fragments were shown to significantly inhibit aggregation and weaken the adsorption of the bacteria to sweet corn seedling roots, thus confirming the role of this protein as an adhesin.

The A. brasilense MOMP exhibited a stronger affinity to cereal roots than to the roots of other plants. Azospirillum spp. is detected mostly in the rhizosphere of cereal and grass species such as corn, wheat, and sorghum (Okon and Vanderleyden 1997). No differences were observed among the tested strains of A. brasilense (Cd, Sp7, and Sp245) in their OMP profile as well as in the binding of their MOMPs to the antiserum (raised with the MOMP of strain $\mathrm{Cd}$ ) and to the various root extracts. It was shown previously that the three strains have similar polymerase chain reaction and Southern hybridization patterns when their total DNA reacts with omaAspecific oligonucleotides and probe, respectively, indicating that the gene encoding the MOMP is conserved strongly in the above strains (Burdman et al. 2000a).

Two different modes of attachment of $A$. brasilense to roots have been proposed: i) rapid, reversible, and weak adsorption, probably mediated by extracellular proteins, including the polar flagellum; and ii) firm and irreversible anchoring by bacterial extracellular polysaccharides (Croes et al. 1993; Michiels et al. 1991). Findings of the present study on the effects of anti-MOMP Fab fragments on root adsorption by $A$. brasilense suggest that the MOMP is involved in the first stage of root adsorption.

A comparative study with various $A$. brasilense strains showed that the amount of exopolysaccharide (EPS) produced by the different strains correlated positively with their extents of aggregation (Burdman et al. 1998). Moreover, the composition of the EPS and capsular polysaccharide (CPS) also differed between the tested strains, with various experiments indicating that presence and concentration of arabinose in the extracellular polysaccharides correlate with the aggregation capability in this bacterium (Burdman et al. 2000b; Castellanos et al. 1998). Therefore, it is possible that the OMP involved in aggregation, probably the MOMP, is constitutively present in A. brasilense, with differences in the extent of aggregation among the various strains being related to the amount, composition, and structure of the extracellular polysaccharide. Interactions between proteins and polysaccharides leading to cell aggregation are well established in the microbial world, examples being the well-characterized systems of Myxobacteria spp. (Dworkin 1996) and dental plaques (Marsh and Bradshaw 1995).

\section{MATERIALS AND METHODS}

\section{Bacterial growth and preparation of $\mathrm{OM}$.}

A. brasilense strains Cd (Eskew et al. 1977), Sp7 (Tarrand et al. 1978), and Sp245 (Baldani et al. 1987) were grown for $24 \mathrm{~h}$ at $30^{\circ} \mathrm{C}$, until late exponential phase, in liquid high carbon-nitrogen $(\mathrm{C}-\mathrm{N})$ medium (Burdman et al. 1998). OM were isolated, as previously described (Burdman et al. 1998), and resuspended in $20 \mathrm{mM}$ Tris- $\mathrm{HCl}(\mathrm{pH} \mathrm{7.2)}$ to give a protein concentration of approximately $2.5 \mathrm{mg}$ per $\mathrm{ml}$, according to Bradford (1976).

\section{Purification of the MOMP.}

For purification of the MOMP, $75 \mu$ lof $100 \mathrm{mM}$ Tris- $\mathrm{HCl}$ buffer ( $\mathrm{pH} 7.2$ ) containing $500 \mathrm{mM} \mathrm{NaCl}, 2 \% \mathrm{SDS}$, and $5 \%$ 
$\beta$-mercaptoethanol were added to $300 \mu \mathrm{l}$ of OM preparation of strain $\mathrm{Cd}$. The sample was then filtered $(0.45 \mu \mathrm{m})$ and loaded onto a Superdex-200 HR10/30 column connected to a FPLC apparatus, AKTA Explorer 100 (Amersham Pharmacia Biotech, Piscataway, NJ, U.S.A.). The running conditions are detailed in Figure 1. Volumes of $0.5 \mathrm{ml}$ were collected with a fraction collector. Fractions suspected to contain the MOMP peak were tested by SDS-PAGE (12\% wt/vol acrylamide), followed by Coomassie brilliant blue G250 staining with the use of standard protocols (Hancock et al. 1979).

\section{Preparation of antiserum} against the MOMP and Western blot analysis.

Rabbit antiserum was obtained according to standard procedures with a Titermax adjuvant (CytRx, Norcross, GA, U.S.A.). For Western blotting, OMPs from strains Cd, Sp7, and Sp245 were electrophoresed in SDS-PAGE, and gels were electroblotted onto Hybond-C extra nitrocellulose membranes (Amersham Pharmacia Biotech), according to Sambrook et al. (1989). The blots were developed by luminescent detection with MOMP antiserum and horseradish peroxidase-conjugated anti-rabbit IgG secondary antiserum (Bio Makor, Rehovot, Israel), both at 1:15,000, and luminol as substrate (Leong and Fox 1990).
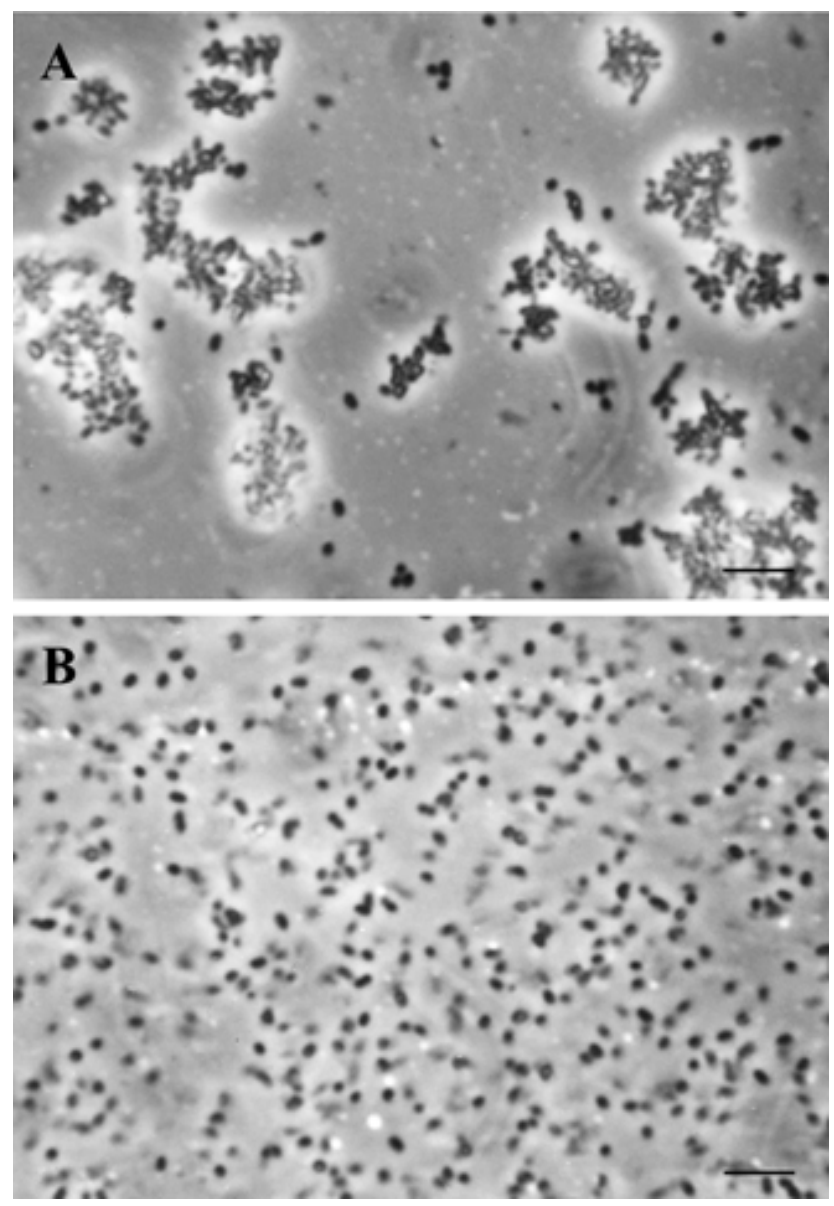

Fig. 5. Agglutination of Azospirillum brasilense Cd cells following incubation with antiserum against the major outer membrane proteins. A, Cells after 10 min of incubation with antiserum; B, control cells. Bars $=10 \mu \mathrm{m}$.

\section{Preparation of root samples}

for affinity screening and adhesion assays.

Sweet corn (cultivar Jubilee), forage corn (646LR-Y), sorghum (FS-5), wheat (Atir), tomato (M-82), common bean (Bulgarian), and chickpeas (Ayelet) were grown aseptically in a hydroponic system, according to Volpin et al. (1996). Roots were collected after 1 week of growth. For preparation of root extracts, root tissue was ground to a fine powder in liquid nitrogen with a mortar and pestle in $2 \mathrm{ml}$ of extraction buffer (1.07 $\mathrm{g}$ of $\mathrm{Na}_{2} \mathrm{HPO}_{4} 7 \mathrm{H}_{2} \mathrm{O}$ per liter; $6.26 \mathrm{~g}$ of $\mathrm{KH}_{2} \mathrm{PO}_{4}$ per liter; and $15 \mathrm{~g}$ of polyvinyl-polypyrrolidone, $\mathrm{pH}$ 5.8, per liter). The mixtures were collected, homogenized for $1 \mathrm{~min}$, and transferred to 2-ml Eppendorf tubes. They were then shaken vigorously and centrifuged at $13,000 \times \mathrm{g}$ for $15 \mathrm{~min}$ at $4^{\circ} \mathrm{C}$. Supernatants were collected, and protein concentration was determined, according to Bradford (1976).

\section{Affinity screening of membrane-immobilized root extracts for the MOMP.}

Root extracts of various plant species were blotted onto Hybond C-extra nitrocellulose membranes (Amersham Phar-

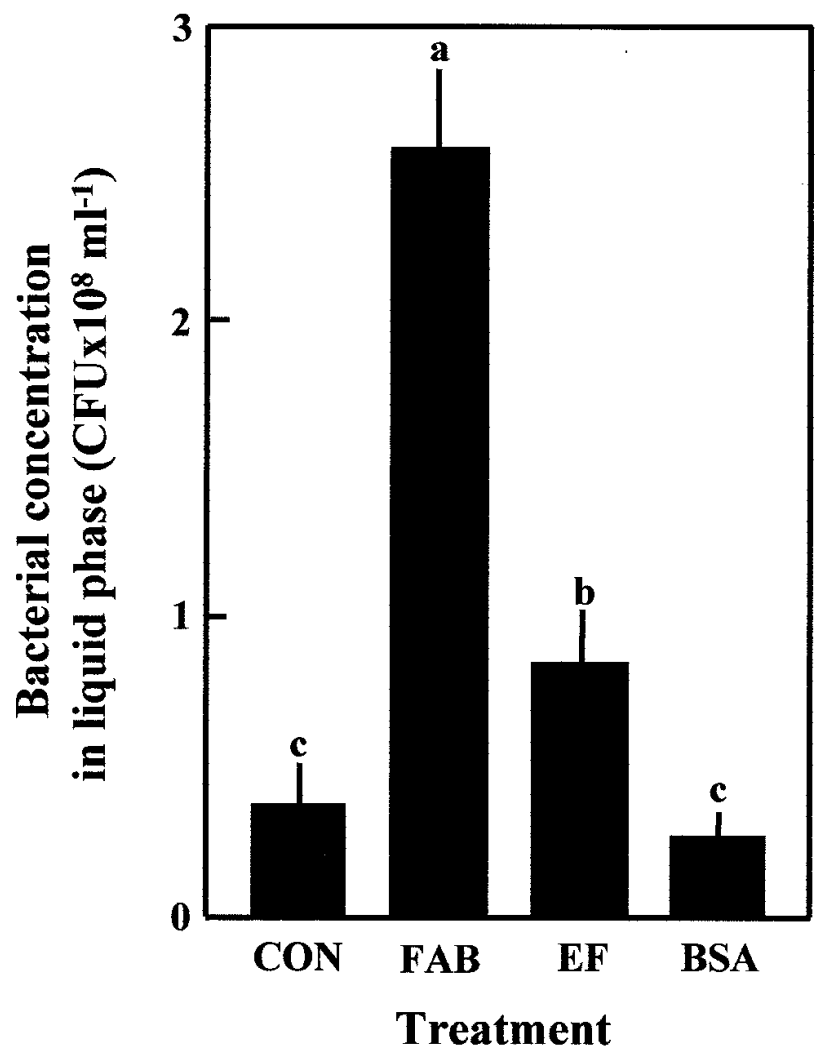

Fig. 6. Effect of anti-major outer membrane protein (MOMP) Fab fragments on cell aggregation of Azospirillum brasilense Cd expressed as the bacterial concentration in the liquid phase (suspension, in contrast to precipitated cells present in flocs) of aggregating cultures following $3 \mathrm{~h}$ of incubation under different treatments. $\mathrm{CON}$, controls; FAB, cells incubated with anti-MOMP Fab fragments; EF, cells incubated with the residual elution fraction obtained from Fab's purification; BSA, bovine serum albumin. Protein concentration in the BSA and EF treatments was the same as with the FAB treatment. Averages and standard errors of four replicates per treatment of one representative experiment (from three with similar results) are presented. Letters indicate significant differences $(p=0.05)$ among treatments, according to one-way analysis of variance. 
macia Biotech), and BSA was used as a control. After adsorption and incubation for $1 \mathrm{~h}$ in blocking solution (3\% skim milk in T-TBS), the nitrocellulose membranes were incubated with $50 \mu \mathrm{l}$ of $\mathrm{OM}$ preparation from strain $\mathrm{Cd}(2.5 \mathrm{mg}$ of protein per $\mathrm{ml})$ diluted in $50 \mathrm{ml}$ of TBS $(20 \mathrm{mM}$ Tris- $\mathrm{HCl}$ and $0.9 \%$ $\mathrm{NaCl}, \mathrm{pH} 7.5$ ) for $1 \mathrm{~h}$ at room temperature. Extensive washes were performed three times in T-TBS (TBS with $0.05 \%$ Tween-20) for 15 min each wash, and detection was carried out by the luminescent reaction, as described for the Western blots.

\section{Adhesion of the MOMP to intact roots.}

One gram of freshly harvested 1-week-old roots of sweet corn seedlings was incubated at $30^{\circ} \mathrm{C}$ for $1 \mathrm{~h}$ in the presence of $50 \mu \mathrm{l}$ of the $\mathrm{OM}$ preparation from strain $\mathrm{Cd}$ in a final volume of $15 \mathrm{ml}$ (20 mM Tris- $\mathrm{HCl}$ buffer, $\mathrm{pH}$ 7.2). Alternatively, the roots were incubated with a similar amount of purified MOMP to that present in the OM preparation. Following incubation, roots were washed three times with $30 \mathrm{ml}$ of sterilized distilled water. Controls for proper washing procedures included roots incubated with BSA at the same protein concentration as the OMPs. Negative controls included roots incubated in Tris buffer alone. Root extracts from the different treatments were prepared by grinding the root tissue to fine powder in liquid nitrogen, as described above. Adhesion of the MOMP to the roots was then assessed by Western blot and luminescent reaction with the use of the above root extracts. Rabbit anti-BSA (Sigma-Aldrich, St. Louis, MO, U.S.A.) at $1: 15,000$ was used for immunodetection of the BSA control.

\section{Preparation of Fab fragments}

from anti-MOMP IgG for inhibition assays.

$\mathrm{IgG}$ were isolated from the MOMP antiserum with a 5-ml HiTrap protein A column (Amersham Pharmacia Biotech) in a FPLC AKTA Explorer 100 and digested with immobilized Papain (Pierce Chemical, Rockford, IL, U.S.A.). Fab fragments were then purified with a 5-ml HiTrap protein G col-

Table 1. Effect of anti-major outer membrane protein Fab fragments on the strength of adherence of Azospirillum brasilense Cd cells to roots of sweet corn seedlings

\begin{tabular}{lcl}
\hline Treatment & Percentage of bacteria attached to roots after vortex \\
\hline Experiment $^{\mathrm{x}}$ & Dilution plating & Radiation counts $^{\mathrm{z}}$ \\
Control & $2.6 \mathrm{a}$ & $12.8 \mathrm{a}$ \\
Fabs & $1.4 \mathrm{~b}$ & $5.7 \mathrm{~b}$ \\
$\mathrm{EF}$ & $2.7 \mathrm{a}$ & Not determined \\
$\mathrm{BSA}$ & $2.9 \mathrm{a}$ & Not determined \\
\hline
\end{tabular}

${ }^{\mathrm{x}}$ Roots were incubated with untreated cells (control) or with Fab fragments (Fabs), with the last eluted fraction from Fabs purification (EF) or BSA (bovine serum albumin). Afterward, they were washed and most of the adhered bacteria were released by vigorous vortex. Values represent the percentage of residual bacteria adhering to the roots after vortex, as determined by dilution plating or by radiation counts. Results represent the averages of four replicates per treatment. Letters indicate significant differences $(p=0.05)$ among treatments, according to one-way analysis of variance.

у $\%=($ CFU per gram of root from root homogenate $) \times 100 /(C F U$ per gram of root from root homogenate $+\mathrm{CFU}$ per gram of root from vortex extract). Values represent results from one of three repetitive experiments with similar results.

$\mathrm{z} \%=($ decompositions per minute $[\mathrm{dpm}]$ per gram of root from washed roots $) \times 100 /(\mathrm{dpm}$ per gram of root from washed roots + dpm per gram of root from vortex extract). Values represent results from one experiment. umn (Amersham Pharmacia Biotech) connected to the FPLC. All steps were performed according to the manufacturers' instructions.

\section{Inhibition assay of cell aggregation with anti-MOMP Fab fragments.}

A. brasilense Cd cells were grown, as previously described, in high $\mathrm{C}-\mathrm{N}$ medium for $16 \mathrm{~h}$ until flocs were visible. The culture was allowed to stand for $10 \mathrm{~min}$, resulting in a flocfree suspension (optical density at 540 of 0.1 ; approximately $4 \times 10^{8} \mathrm{CFU} / \mathrm{ml}$ ). These cells were collected and used for testing inhibition of aggregation, and $160 \mu \mathrm{l}$ of the cell suspension were mixed with $40 \mu \mathrm{l}$ of Fab solution $(0.5 \mu \mathrm{g}$ per $\mu \mathrm{l})$ and incubated in 1.5-ml Eppendorf tubes for $3 \mathrm{~h}$ at $30^{\circ} \mathrm{C}$ with shaking. For use as controls, cells were incubated with $20 \mathrm{mM}$ Tris-HCl buffer ( $\mathrm{pH}$ 7.2), BSA, or with the same volume of EF, which contained some residual Fab fragments but mainly Fc chains. Inhibition of cell aggregation was estimated qualitatively by visual comparison of the sedimented flocs and quantitatively by dilution plating of the free cell-containing suspensions.

\section{Effects of anti-MOMP Fab fragments on root adhesion of $A$. brasilense.}

A. brasilense $\mathrm{Cd}$ cells were grown for $20 \mathrm{~h}$ in low $\mathrm{C}-\mathrm{N}$ medium to prevent floc formation (Burdman et al. 1998), then washed twice and resuspended in $50 \mathrm{mM}$ phosphate saline buffer (PBS) to a final concentration of $5 \times 10^{7} \mathrm{CFU} / \mathrm{ml}$. Afterward, $160 \mu \mathrm{l}$ of cell suspension were preincubated for $1 \mathrm{~h}$ at

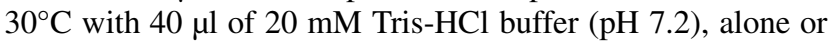
with $0.5 \mu \mathrm{g}$ of Fab fragments, EF, or BSA per $\mu$, then transferred to conical tubes containing $9.8 \mathrm{ml}$ of PBS and 0.3 to 0.5 $\mathrm{g}$ of excised roots from 1-week-old sterile sweet corn seedlings. After a $1-\mathrm{h}$ incubation at $25^{\circ} \mathrm{C}$ with gentle shaking, the roots were transferred to new tubes and washed three times with PBS. Following the addition of $5 \mathrm{ml}$ of PBS, the tubes were submitted to vigorous vortex for $10 \mathrm{~min}$ and the amount of cells released from the roots was measured by dilution plating. In order to release bacteria that were bound more firmly to the roots, the roots were washed again, resuspended in $3 \mathrm{ml}$ of PBS containing $0.2 \%$ polyvinyl-polypyrrolidone and $0.05 \%$ Tween 20 , and homogenized with a RzR 50 tissue homogenizer (Heidolph, Kelheim, Germany). Additional bacteria released from the roots were quantified by dilution plating.

In a second experiment, bacteria were grown and washed, as described above, and incubated for $3 \mathrm{~h}$ at $30^{\circ} \mathrm{C}$ in $1: 10$ low $\mathrm{C}-\mathrm{N}$ medium containing $0.3 \mu \mathrm{C} \mathrm{D}-[\mathrm{U}-14 \mathrm{C}]$-fructose per $\mathrm{ml}$ (Amersham). The cells were washed three times to remove residual radiolabeled fructose. The experiment was carried out as above. Radiation counts were taken from the PBS solution after the vigorous vortex step and from the remaining washed roots.

\section{Statistical analysis.}

All experiments were performed three times, with the exception of the radioactive experiment on inhibition of adhesion of $A$. brasilense to roots, which was carried out once. When required, statistical analysis was performed with oneway analysis of variance. 


\section{ACKNOWLEDGMENTS}

We express our sincere appreciation to J. Vanderleyden and to R. De Mot from the F. A. Janssens Laboratory of Genetics (Catholic University of Leuven, Belgium) for their extensive cooperation, and to $\mathrm{M}$. Levendiker from the Protein Purification Unit (Life Science Institute, Hebrew University of Jerusalem, Israel) for his help in the purification of the anti-MOMP Fabs. This research was supported by The Israel Science Foundation founded by the Academy of Sciences and Humanities. G. Dulguerova's work was supported by a short-term UNESCO Fellowship in Biotechnology.

\section{LITERATURE CITED}

Achouak, W., De Mot, R., and Heulin, T. 1995. Purification and partial characterization of an outer membrane protein involved in the adhesion of Rhanella aquatilis to wheat roots. FEMS Microbiol. Ecol. 16:19-24.

Bachhawat, A. K., and Ghosh, S. 1987. Isolation and characterization of the outer membrane proteins of Azospirillum brasilense. J. Gen. Microbiol. 133:1751-1758.

Baldani, V. I. D., Baldani, J. I., and Döbereiner, J. 1987. Inoculation of field-grown wheat with Azospirillum brasilense spp. Braz. Biol. Fertil. Soils 4:37-40.

Bradford, M. M. 1976. A rapid and sensitive method for quantification of microgram quantities of protein utilizing the principle of protein dye binding. Anal. Biochem. 72:248-254.

Burdman, S., Jurkevitch, E., Schwartsburd, B., Hampel, M., and Okon, Y. 1998. Aggregation in Azospirillum brasilense: Effects of chemical and physical factors and involvement of extracellular components. Microbiology 144:1989-1999.

Burdman, S., Jurkevitch, E., Schwartsburd, B., and Okon, Y. 1999. Involvement of outer membrane proteins in aggregation of Azospirillum brasilense. Microbiology 145:1145-1152.

Burdman, S., De Mot, R., Vanderleyden, J., Okon, Y., and Jurkevitch, E. 2000a. Identification and characterization of the omaA gene encoding the major outer membrane protein of Azospirillum brasilense. DNA Sequence. 11:225-257.

Burdman, S., Jurkevitch, E., Soria-Díaz, M. E., Gil Serrano, A. M., and Okon, Y. 2000b. Extracellular polysaccharide composition of Azospirillum brasilense and its relation with cell aggregation. FEMS Microbiol. Lett. 189:259-264.

Burdman, S., Okon, Y., and Jurkevitch, E. 2000c. Surface characteristics of Azospirillum brasilense in relation to cell aggregation and attachment to plant roots. Crit. Rev. Microbiol. 26:91-110.

Castellanos, T., Ascencio, F., and Bashan, Y. 1998. Cell-surface lectins of Azospirillum spp. Curr. Microbiol. 36:241-244.

Croes, C. L., Moens, S., Van Bastelaere, E., Vanderleyden, J., and Michiels, K. W. 1993. The polar flagellum mediates Azospirillum brasilense adsorption to wheat roots. J. Gen. Microbiol. 139:2261-2269.

De Mot, R., and Vanderleyden, J. 1991. Purification of a root-adhesive outer membrane protein of root-colonizing Pseudomonas fluorescens. FEMS Microbiol. Lett. 81:323-328.

De Troch, P., and Vanderleyden, J. 1996. Surface properties and motility of Rhizobium and Azospirillum in relation to plant root attachment. Microbiol. Ecol. 32:149-169.

Dworkin, M. 1996. Recent advances in the social and developmental biology of the Myxobacteria. Microbiol. Rev. 60:70-102.

Eskew, D. L., Focht, D. D., and Ting, I. P. 1977. Nitrogen fixation, denitrification and pleomorphic growth in highly pigmented Spirillum lipoferum. Can. J. Microbiol. 34:582-585.

Hancock, R. E. W., and Carey, A. M. 1979. Outer membrane of Pseudomonas aeruginosa: Heat and 2-mercaptoethanol-modifiable proteins. J. Bacteriol. 140:902-910.

Leong, M. M. L., and Fox, G. R. 1990. Luminescent detection of immunodot and western blots. Methods Enzymol. 184:442-451.

Marsh, P. D., and Bradshaw, D. J. 1995. Dental plaque as a biofilm. J. Ind. Microbiol. 15:169-175.

Michiels, K. W., Croes, C. L., and Vanderleyden, J. 1991. Two different modes of attachment of Azospirillum brasilense $\mathrm{Sp} 7$ to wheat roots. J. Gen. Microbiol. 137:2241-2246.

Okon, Y., and Labandera-Gonzalez, C. A. 1994. Agronomic applications of Azospirillum. An evaluation of 20 years worldwide field inoculation. Soil Biol. Biochem. 26:1591-1601.

Okon, Y., and Vanderleyden, J. 1997. Root-associated Azospirillum species can stimulate plants. ASM News 63:366-370.

Sadasivan, L., and Neyra, C. A. 1985. Flocculation in Azospirillum brasilense and Azospirillum lipoferum: Exopolysaccharides and cyst formation. J. Bacteriol. 163:716-723.

Sambrook, J., Fritsch, E. F., and Maniatis, T. 1989. Molecular Cloning: A Laboratory Manual. 2nd ed. Cold Spring Harbor Laboratory, Cold Spring Harbor, NY, U.S.A.

Tarrand, J. J., Krieg, N. R., and Döbereiner, J. 1978. A taxonomic study of the Spirillum lipoferum group with the description of a new genus, Azospirillum gen. nov. and two species, Azospirillum lipoferum (Beijerinck) comb. nov. and Azospirillum brasilense sp. nov. Can. J. Microbiol. 24:967-980.

Volpin, H., Burdman, S., Castro-Sowinski, S., Kapulnik, Y., and Okon, Y. 1996. Inoculation with Azospirillum increased exudation of rhizobial nod-gene inducers by alfalfa roots. Mol. Plant-Microbe Interact. 9:388-394. 